\title{
PROSPEK PENGEMBANGAN KERJASAMA ANTAR DAERAH KABUPATEN/KOTA DI KALIMANTAN TIMUR DALAM PENYELENGGARAAN URUSAN PEMBANGUNAN DAN PELAYANAN MASYARAKAT ${ }^{21}$
}

\author{
Oleh: Tri Widodo W. Utomo, SH.,MA ${ }^{22}$
}

\begin{abstract}
The promulgation of extended-decentralization policy has brought about the competition climate among district/city governments in delivering public services. The capacity to accomplish public tasks, however, tends to be insufficient. That's why, regional-cooperation-based management is believed as the paramount mode to minimize local government's shortage on the one hand, and to improve public accountability and performance on the other hand. In the East Kalimantan case, the tradition of conducting public affairs through collaborative management seems to be disregarded. Nevertheless, the prospect to intensify regional cooperation is fairly promising. This paper examines the likely development cooperation among three autonomous regions, i.e. Bontang City, East Kutai District, and Kutai Kartanegara District, the Bosanggarong (Bontang, Sangatta, and Tenggarong) Development Forum. The study has been highlighted on three dimension of development: provision of basic infrastructure facilities (public works), environmental management, and garbage / waste-disposal services.
\end{abstract}

Keywords: Otonomi / desentralisasi, kerjasama antar daerah, pelayanan masyarakat.

\section{Pengantar}

Kebijakan otonomi luas (big bang decentralization) yang berkembang pesat sejak 1999 telah menempatkan daerah (khususnya kabupaten/kota) sebagai ujung tombak penyelenggaraan fungsi pelayanan umum dan pembangunan. Sejalan dengan hal tersebut, maka daerah diberikan kewenangan yang luas untuk menjalankan urusan-urusan pemerintahan, serta hak untuk menggali berbagai potensi dan sumber pendapatan guna mendukung implementasi urusan-urusan pemerintahan tadi secara optimal. Dengan kewenangan dan hak otonom yang jauh lebih luas dan lebih besar tadi, maka wajarlah jika kebijakan otonomi telah mendorong lahirnya iklim kompetisi antar daerah dalam membangun daerahnya.

21 Makalah ini merupakan saduran dari hasil penelitian tahun 2005 yang dilaksanakan oleh Balitbang Provinsi Kalimantan Timur bekerjasama dengan PKP2A III LAN Samarinda dengan tema "Kajian Tentang ModelModel Kerjasama Regional dan Prospek Kerjasama Penyelenggaraan Urusan Pemerintahan Lintas Daerah Kabupaten/Kota di Kalimantan Timur”. Dalam penelitian tersebut, penulis berkedudukan sebagai Tenaga Ahli sekaligus koordinator penulisan dan penyuntingan hasil laporan.

22 Kepala Bidang Kajian Aparatur PKP2A III LAN Samarinda; Peneliti Madya Bidang Administrasi; dan Dosen Luar Biasa pada Universitas Widyagama Mahakam Samarinda. 
Kondisi diatas mengilustrasikan dengan cukup jelas bahwa kebijakan otonomi daerah sesungguhnya memberikan tanggungjawab dan beban kerja yang jauh lebih berat kepada daerah, dibanding pada masa-masa sebelumnya. Sementara disisi lain, pemerintah daerah masih dihadapkan pada berbagai permasalahan klasik berupa keterbatasan kualitas dan kuantitas sumber daya, baik anggaran, SDM maupun sarana dan prasarana. Hal ini mengharuskan jajaran aparat daerah untuk berpikir secara kreatif dan inovatif untuk membangun sistem manajemen pemerintahan yang lebih efektif dan efisien.

Salah satu strategi yang dapat ditempuh disini adalah dengan mengembangkan polapola partisipasi, kerjasama, dan kemitraan dalam penyelenggaraan suatu urusan dan/atau kewenangan tertentu. Selain karena alasan keterbatasan sumber daya, urgensi penyelenggaraan kerjasama juga didorong oleh adanya perkembangan dinamika kehidupan masyarakat yang semakin tinggi. Sebagai akibat dari dinamika masyarakat yang tinggi tadi, interaksi masyarakat di bidang-bidang ekonomi, sosial, maupun kepemerintahan tidak lagi berlangsung pada lingkup suatu daerah otonom saja, melainkan telah melebar hingga melewati batas wilayah daerah yang bersangkutan.

UU No. 32 Tahun 2004 tentang Pemerintahan Daerah sendiri telah memberikan legalitas yang besar untuk dilaksanakannya kerjasama pembangunan, baik dengan pihak ketiga (publik atau swasta) maupun kerjasama antar daerah yang bertetangga. Dalam pasal 195 (1) dinyatakan bahwa "Dalam rangka meningkatkan kesejahteraan rakyat, daerah dapat mengadakan kerja sama dengan daerah lain yang didasarkan pada pertimbangan efisiensi dan efektifitas pelayanan publik, sinergi dan saling menguntungkan.” Bahkan pasal 196 (2) lebih tegas lagi berisi "perintah” untuk membuat kerjasama antar daerah, dengan menyatakan: "Untuk menciptakan efisiensi, daerah wajib mengelola pelayanan publik secara bersama dengan daerah sekitarnya untuk kepentingan masyarakat.”

Paparan diatas mengilustrasikan adanya sebuah trend baru administrasi publik, yakni adanya keterkaitan (interconnection) dan saling ketergantungan (interdependence) antara pemerintah daerah yang satu dengan pemerintah daerah lainya dalam penyelenggaraan urusan dan/atau kewenangan tertentu. Dengan kata lain, kerjasama antar daerah merupakan keniscayaan dalam manajemen pemerintahan daerah pada masa mendatang. Untuk itu, perlu adanya suatu kajian yang cukup komprehensif dan mendalam tentang berbagai hal yang berhubungan dengan model-model dan kelembagaan kerjasama antar daerah.

Disisi lain harus diakui bahwa dalam pola atau model kerjasama apapun tidak akan lepas dari kemungkinan terjadinya benturan kepentingan, perbedaan penafsiran, atau kegagalan dalam memenuhi kewajiban satu pihak terhadap pihak lainnya. Dengan kata lain, selain sebagai cara meredam konflik, suatu kerjasama tidak jarang justru menjadi sumber sengketa baru. Untuk itu, pengembangan kerjasama antar daerah harus diikuti dengan pengaturan yang jelas dan tegas tentang kedudukan, hak, dan kewajiban, masing-masing pihak, serta mekanisme resolusi konflik dalam hal timbul friksi akibat dilakukannya suatu kerjasama. Itulah sebabnya, kejelasan tentang penanganan dan penyelesaian perselisihan antar daerah juga perlu mendapat pengkajian yang cermat agar tidak mengganggu efektivitas roda pemerintahan daerah. 
Dalam konteks pengembangan model kerjasama antar daerah, Propinsi Kalimantan Timur dapat dikatakan sebagai wilayah yang sangat potensial untuk menerapkan pola-pola kerjasama dalam penyelenggaraan pemerintahan daerah. Sebab secara geografis, Kalimantan Timur yang merupakan propinsi terluas di Indonesia hanya memiliki 13 kabupaten/kota. Dalam perspektif kedepan, Kalimantan Timur jelas sangat terbuka terhadap kebijakan pemekaran wilayah. Disamping itu, dilihat dari potensi sumber daya alam (SDA), Kalimantan Timur juga sangat kaya dengan beragam kekayaan tambang, hasil hutan, maupun potensi perikanan (darat maupun laut). Berbagai kekayaan alam tersebut tersebar hampir merata di seluruh daerah, sehingga dalam pengelolaannya pun membutuhkan kerjasama yang harmonis antar daerah.

Berdasarkan uraian dan pertimbangan diatas, maka dipandang perlu untuk melakukan kajian tentang model-model kerjasama antar daerah (kerjasama regional) dan prospek kerjasama penyelenggaraan urusan pemerintahan lintas daerah di wilayah Kalimantan Timur. Dengan adanya kajian megenai hal ini, diharapkan dapat dilakukan identifikasi terhadap berbagai kondisi, permasalahan, dan kemungkinan alternatif kebijakan yang dapat dikembangkan untuk mendorong semakin erat dan kuatnya kerjasama antara beberapa pemerintah daerah di wilayah regional tertentu.

\section{Metodologi Penelitian}

Berdasarkan tujuannya, metode penelitian yang akan akan dilakukan ini adalah metode deskriptif eksploratif, yang dirancang untuk dapat menguraikan, menjawab, dan menjabarkan kondisi-kondisi pada bidang pelayanan persampahan dan kebersihan, pengelolaan lingkungan, serta penyediaan fasilitas infrastruktur, berdasarkan pokok-pokok permasalahan penelitian. Sedangkan teknik dan/atau instrumen pengumpulan data yang digunakan adalah penyebaran dan pengisian kuesioner, serta penjaringan data sekunder untuk menunjang analisis, seperti laporan kegiatan, hasil penelitian, dokumen perencanaan, dan sebagainya.

Mengingat sangat luasnya bidang-bidang atau sektor-sektor, atau urusan pemerintahan yang dapat dikerjasamakan, maka perlu dilakukan pembatasan terhadap ruang lingkup penelitian. Dalam hubungan ini, kajian akan diarahkan kepada issu-issu pembangunan dan pelayanan publik yang banyak dihadapi oleh masyarakat dalam kehidupan sehari-hari. Issu-issu aktual tersebut meliputi aspek pelayanan kebersihan dan persampahan, penyediaan dan pemeliharaan infrastruktur fisik (khususnya jalan dan jembatan), dan pengelolaan lingkungan.

Disamping pembatasan terhadap substansi penelitian, perlu pula dilakukan pembatasan jangkauan wilayah kajian mengingat luasnya wilayah Kalimantan Timur. Dalam hal ini, teknis pengambilan sample penelitian dilakukan secara purposive, dengan mempertimbangkan aspek karakteristik daerah dan tingkat urgensi terhadap pengembangan kerjasama antar daerah. Atas dasar pertimbangan tersebut, maka sample yang dipilih dalam penelitian ini terdiri dari 3 (tiga) daerah, yakni: Kota Bontang, Kabupaten Kutai Kartanegara, dan Kabupaten Kutai Timur. Forum kerjasama ketiga daerah ini diusulkan dengan nama Bosanggarong (Bontang, Sangatta, Tenggarong). 


\section{Pengertian dan Esensi Kerjasama Antar Daerah}

Dalam era desentralisasi luas dewasa ini, terjadi proses perubahan pola pemerintahan yang didominasi oleh rezim Pusat menjadi pola pemerintahan yang lebih berbasis pada kemandirian daerah dengan mengandalkan optimalisasi sumber daya serta pengembangan kolaborasi antar pilar dan/atau aktor pembangunan. Dengan kata lain, peran pemerintah Pusat semakin mengecil, sementara peran pemerintah daerah harus semakin diperkuat. Ini berarti pula bahwa kebijakan otonomi hanya akan berhasil jika diikuti oleh peningkatan kapasitas daerah yang lebih berbasis pada kemampuan pengelolaan yang unggul (managerialism).

Walaupun mengecilnya peran pemerintah adalah hal yang normal dalam era otonomi, tidak berarti bahwa pemerintah cukup hanya bertindak sebagai pendukung bagi berjalannya proses pembangunan. Justru dalam konteks perubahan pola hubungan tadi, pemerintah (baik Pusat maupun Daerah) harus menggalang kekuatan dengan komponen masyarakat lainnya demi mewujudkan tujuan pembangunan secara keseluruhan. Dan disinilah letak pentingnya kerjasama baik kerjasama antar pemerintahan (government to government), kerjasama pemerintah dengan swasta (government to business), serta kerjasama pemerintah dengan masyarakat (government to civil society).

Pola pikir perlunya kerjasama regional di era otonomi ini adalah bahwa desentralisasi mungkin sekali akan menciptakan pihak-pihak yang untung disatu sisi dan pihak-pihak yang merugi disisi lain (winners and losers). Pada situasi tadi, hanya pihak-pihak yang memiliki kapasitas unggul dan manajemen yang efektif saja yang bisa memperoleh sumber-sumber daya untuk mempercepat pertumbuhan usaha atau organisasinya. Untuk mengatasi situasi yang kurang menguntungkan semacam itu, kerjasama regional (antar daerah) lagi-lagi menawarkan jalan keluar terbaik.

Dalam beberapa hal, pengertian kerjasama (cooperation) seringkali disamakan dengan kemitraan (partnership). Dalam hal ini, Kamus Umum Bahasa Indonesia dan Cambridge International Dictionary of English memberikan batasan yang hampir sama, dimana kerjasama didefinisikan sebagai kegiatan atau usaha yang dilakukan oleh beberapa pihak (lembaga, pemerintah, dan sebagainya) untuk mencapai tujuan bersama (to act work together for a particular purpose, or to help someone willingly when help is requested); sedangkan kemitraan didefinisikan sebagai perihal hubungan (jalinan kerja sama dan sebagainya) sebagai mitra (partnership is the state for being a partner).

Sementara itu dalam khazanah akademik, Flo Frank and Anne Smith (2000: 5) menyatakan bahwa kerjasama dapat didefinisikan sebagai suatu hubungan dua pihak atau lebih yang mempunyai tujuan bersama, yang berjanji untuk melakukan sesuatu bersama-sama. Kerjasama adalah tentang orang-orang yang bekerjasama bersama-sama dalam suatu hubungan yang menguntungkan, selalu mengerjakan sesuatu hal bersama-sama yang mungkin tidak dapat dicapai sendirian (dalam LAN, 2004). Adapun dalam acuan Intergovernmental Cooperation, kerjasama antar pemerintahan didefinisikan sebagai suatu susunan antara dua pemerintah atau lebih untuk mencapai tujuan-tujuan bersama, penyediaan suatu layanan atau memecahkan masalah satu sama lain secara bersama. 
Dari kedua definisi yang telah dikemukakan, maka dapat disimpulkan bahwa kerjasama antar daerah adalah satu tindakan, kegiatan atau usaha yang dilakukan bersamasama oleh dua atau lebih daerah otonom, yang dilakukan dalam rangka mencapai tujuan bersama untuk mengatur dan mengurus kepentingan masyarakat.

Kerjasama antar daerah secara umum terjadi karena beberapa hal, diantaranya adalah adanya saling ketergantungan dalam aktivitas ekonomi; perbedaan dalam kepemilikan sumber daya; kebutuhan spesialisasi dengan maksud meningkatkan nilai tambah suatu daerah; serta karena kondisi geografis dan karakteristik yang berbeda. Dalam hal ini, paling tidak terdapat 2 (dua) jenis kerjasama antar daerah, yakni:

a. Kerjasama antar dua pemerintah daerah dimana salah satu pemerintah daerah melakukan perjanjian kerjasama dengan pemerintah daerah lainnya untuk menyediakan pelayanan berdasarkan harga yang telah ditetapkan. Kategori ini dikenal sebagai kerjasama pelayanan.

b. Kerjasama dimana kepentingan pemerintah-pemerintah daerah yang berpartisipasi setuju untuk bersama-sama menanggung dalam hal pelaksanaan fungsi-fungsi atau pembangunan dan pengoperasian suatu fasilitas. Kategori ini dikenal sebagai kerjasama pembangunan dan pengelolaan.

Esensi atau pentingnya kerjasama dalam pemberian pelayanan tertentu atau dalam pengelolaan aspek pembangunan tertentu didorong oleh alasan-alasan obyektif sebagai berikut:

a. Penggalian dan pemanfaatan sumber daya potensial yang saling menguntungkan.

b. Penyiapan daya dukung lingkungan bagi terciptanya kerjasama antar daerah dan proses pembangunan yang berkelanjutan.

c. Fasilitasi penyelesaian perselisihan kerjama antar daerah guna menghindari konflik kepentingan akibat perbedaan persepsi yang bernuansa ego sektoral dan kepentingan jangka pendek.

d. Terciptanya keselarasan, kesesuaian, keserasian dengan prinsip integral dan terjadinya pemahaman yang baik terhadap keseimbangan pertumbuhan perekonomian daerah.

e. Perumusan kebijakan agar tercipta kesatuan, pola pikir dan tindakan antar daerah yang dilandasi prinsip saling memahami berorientasi kepada pemberian solusi bagi kepentingan masyarakat yang lebih luas.

Sementara itu dalam laporan hasil penelitiannya, PKP2A I (2004) menyebutkan bahwa pertimbangan atau alasan-alasan tentang perlunya memperkuat kerjasama antar daerah maupun kerjasama antara sektor publik dengan publik sektor privat, paling tidak dapat dilihat dari 3 dimensi sebagai berikut:

- Alasan politis: menciptakan pemerintah yang demokratis (egalitarian governance) serta untuk mendorong perwujudan good governance and good society.

- Alasan administratif: adanya keterbatasan sumber daya pemerintah (government resources), baik dalam hal anggaran, SDM, asset, maupun kemampuan manajemen.

- Alasan ekonomis: mengurangi kesenjangan (disparity) atau ketimpangan (inequity), memacu pertumbuhan (growth) dan produktivitas, meningkatkan kualitas dan kontinuitas (quality and continuity), serta mengurangi resiko (risk minimization). 
Dilihat dari pendekatan teoretis, adanya kerjasama antar daerah memang dipercaya dapat menghasilkan berbagai dampak yang signifikan bagi pihak-pihak yang terlibat dalam kerjasama tersebut. Dalam hubungan ini, Municipal Cooperation Guide (dalam LAN: 2004) menyebutkan bahwa keuntungan yang dapat diraih dari adanya kerjasama antar daerah antara lain adalah:

- Meningkatkan efisiensi unit-unit operasional.

- Pemerintah daerah dapat memperoleh pelayanan atau produk yang tidak dapat dihasilkan sendiri atau yang hanya dapat dibuat dengan biaya tinggi.

- Menghapuskan duplikasi usaha.

- Beberapa masalah yang dihadapi pemerintah daerah dapat dipecahkan tanpa mengubah struktur dasar dari sistem pemerintah daerah.

Pendapat lain mengenai manfaat kerjasama antar daerah dikemukakan oleh Peter Knip (dalam LAN: 2004) sebagai berikut:

- Memberi kontribusi bagi penguatan pemerintah daerah, karena kerjasama antar daerah mengedepankan pembangunan yang demokratis dan berkelanjutan.

- Daerah yang sedang membangun dan berada pada tahap transisi, dimana tanggung jawab pemerintah daerah meluas secara cepat akibat dari desentralisasi, mempunyai kebutuhan nyata untuk bertukar pengalaman dengan daerah-daerah yang telah maju. Kerjasama antar daerah secara efektif menjembatani kebutuhan tersebut.

- Memberi kontribusi pada peluang pembangunan berbasis partisipasi masyarakat.

Meskipun kerjasama regional ini menjanjikan banyak sisi positif, namun ada juga kemungkinan menimbulkan hal yang sebaliknya. Dampak negatif dapat muncul jika terpenuhi kondisi-kondisi antara lain: tidak jelasnya naskah dan konsep perjanjian kerjasama, tidakk sejajarnya kedudukan antar pihak yang melakukan kerjasama, kurang adanya perencanaan yang matang dan pengendalian yang ketat, dan sebagainya.

\section{Tipe-tipe Kerjasama Antar Daerah}

Mengenai tipe-tipe atau bentuk kerjasama regional, Utomo (2004) mengklasifikasikan menjadi 3 (tiga) jenis berdasarkan anggota yang tergabung dalam forum kerjasama tersebut, yakni:

1. Kerjasama pembangunan antar propinsi (inter-provinces development cooperation). Forum kerjasama seperti ini terdiri dari beberapa propinsi yang berdekatan, misalnya Forum Pembangunan Sumatra, atau Forum Komunikasi Gubernur se Sulawesi.

2. Kerjasama pembangunan antara propinsi dengan kabupaten/kota di sekitarnya, misalnya Badan Kerjasama Jabotabek (Jakarta, Bogor, Tangerang dan Bekasi). Wilayah kabupaten/kota yang mengelilingi propinsi tadi pada umumnya berfungsi sebagai wilayah penyangga (hinterland), misalnya sebagai wilayah permukiman, pembuangan sampah, wilayah resapan, dan sebagainya. Dengan demikian, hubungan yang terjadi adalah hubungan antara pusat dengan pinggiran (the central - periphery relationship).

3. Kerjasama pembangunan antara kabupaten/kota. Forum ini terdiri dari beberapa daerah otonom dalam satu propinsi atau lebih. Secara lebih dalam, forum ini dapat dibedakan menjadi 3 (tiga) tipe, yaitu:

- Kerjasama pembangunan antara dua atau lebih kabupaten/kota yang berada cukup jauh dari pusat kota propinsi. Contoh kerjasama dengan pola ini adalah Barlingmascakeb (Banjarnegara, Purbalingga, Banyumas, Cilacap and Kebumen).

- Kerjasama pembangunan antara dua atau lebih kabupaten/kota, yang salah satu diantaranya berfungsi pula sebagai ibukota propinsi. Contoh kerjasama dengan pola ini adalah forum pembangunan Bandung Raya.

- Kerjasama pembangunan antara dua atau lebih kabupaten/kota dalam wilayah provinsi 
yang berbeda. Contoh kerjasama dengan pola ini adalah Pawonsari (Kab. Pacitan di

Jawa Timur, Kab. Wonogiri di Jawa Tengah, serta Gunungkidul atau Wonosari di Propinsi DIY).

Sementara itu menurut LAN (2004), pada prinsipnya kerjasama antar daerah dapat dilakukan pada semua tingkat pemerintah daerah yang memiliki hak otonom. Kerjasama antar daerah dapat dilakukan antara:

a. Pemerintah provinsi dengan pemerintah provinsi lainnya;

b. Pemerintah kota/kabupaten dengan pemerintah kota/kabupaten yang berada dalam satu wilayah provinsi;

c. Pemerintah kota/kabupaten dengan pemerintah kota/kabupaten yang berada di lain wilayah provinsi;

d. Pemerintah provinsi dengan pemerintah kota/kabupaten yang berada di wilayah provinsi yang sama;

e. Pemerintah provinsi dengan pemerintah kota/kabupaten yang berada di wilayah provinsi yang berlainan.

Selain tipe kerjasama diatas, pada saat yang bersamaan perlu dipikirkan pula model pembiayaan bagi kerjasama yang dilakukan. Dalam hal ini, Intergovernmental Cooperation Handbook mengemukakan bahwa ketika suatu kerjasama akan diselenggarakan, pemerintah daerah harus memutuskan berbagai pilihan alternatif model kerjasama pembagian pola atau model pembiayaan yang dianggap paling adil. Seringkali dipilih suatu kombinasi model pembagian pembiayaan kerjsama untuk menyeimbangkan perbedaan pandangan tentang keadilan. Berbagai model pembiayaan yang dapat dilakukan dalam penyelenggaraan kerjasama antar daerah antar lain adalah:

a. Model pembagian pembiayaan secara merata (equal share).

b. Model pembagian pembiayaan berdasarkan jumlah populasi.

c. Model pembagian pembiayaan berdasarkan perhitungan tingkat nilai partisipasi.

d. Model pembagian pembiayaan berdasarkan tingkat penggunaan fasilitas.

\section{Kerangka Kebijakan Pengembangan Kerjasama Antar Daerah}

Dalam kerangka kebijakan, kerjasama antar daerah mendapat pengaturan cukup lengkap dalam UU Pemerintahan Daerah. Dalam UU No. 22/1999, misalnya, telah diatur mengenai aspek kerjasama antar daerah ini. Namun nampaknya, belum banyak daerah yang mengambil inisiatif untuk mengembangkan pola kerjasama antar unit pemerintahan daerah ini. Pengaturan tentang aspek kerjasama dan penyelesaian perselisihan yang muncul akibat kerjasama tersebut, selengkapnya diatur dalam pasal 87-89 UU No. 22/1999. Sementara dalam UU No. 32/2004 yang menggantikan UU No. 22/1999, pengaturan tentang kerjasama antar daerah tertuang dalam pasal 195-198. Dari pengaturan yang terdapat dalam kedua UU diatas, dapat dilakukan interpretasi mengenai beberapa dimensi strategis kerjasama sebagai berikut:

1. Dalam aspek kelembagaan, baik UU No. 22/1999 maupun UU No. 32/2004 menegaskan bahwa kerjasama antar daerah dapat diwujudkan dalam bentuk Badan Kerjasama yang diatur dengan keputusan bersama. Adanya lembaga khusus untuk menjalankan materi kerjasama ini memang penting, namun yang lebih penting lagi adalah bagaimana pemerintah daerah dapat bekerjasama tanpa harus tergantung pada pembentukan lembaga tadi. Dengan kata lain, pembentukan lembaga khusus yang mengelola kerjasama ini akan lebih efektif untuk kepentingan jangka panjang, sedangkan untuk jangka pendek belum merupakan kebutuhan mendesak. Sebab, pembentukan lembaga baru selain memerlukan 
proses yang cukup panjang, juga membutuhkan sumber daya yang tidak sedikit. Oleh karena itu, harus diusahakan agar pembentukan Badan Kerjasama tadi justru tidak menghambat pelaksanaan kerjasama itu sendiri.

2. Dalam aspek penyelesaian perselisihan, terdapat sedikit perbedaan antara ketentuan UU No. 22/199 dengan ketentuan UU No. 32/2004. Berdasarkan ketentuan pasal 198, nampak bahwa UU Nomor 32/2004 lebih mengedepankan banding administratif vertikal sebagai satu-satunya prosedur beracara. Hal ini dapat disimak dari bunyi ayat (3) bahwa keputusan pejabat yang diberi wewenang memutuskan sengketa itu bersifat final (tidak dapat dilakukan upaya hukum lain). Tentu saja, ketentuan seperti ini berpotensi menimbulkan adanya “permasalahan tanpa penyelesaian”. Sebab bagaimanapun juga, UU No. 5/1986 jo. UU No. 9/2004 tentang PTUN merupakan landasan utama dalam penyelesaian sengketa administrasi / tata usaha negara. Dengan kata lain, UU No. 5/1986 jo. UU No. 9/2004 merupakan lex specialis dari UU No. 32/2004 dalam hal penyelesaian sengketa administrasi / tata usaha negara. Dan sesuai kaidah hukum, maka hukum yang lebih khusus dapat meniadakan hukum yang bersifat umum (lex specialis derogat lex generalis). Terlebih lagi, pasal 198 tadi tidak menyediakan upaya hukum lain dalam hal terjadi ketidakpuasan dari salah satu pihak yang berselisih atas putusan Gubernur atau Mendagri yang bersifat final. Dalam pandangan ilmu hukum, cara penyelesaian sengketa yang hanya ditempuh dengan satu upaya hukum saja (apalagi lembaga tersebut bukan lembaga hukum), adalah hal yang kurang masuk akal. Dalam konteks seperti ini, maka pengaturan pada UU No. 22/1999 jauh lebih baik karena masih menyediakan upaya hukum lain, yakni dalam bentuk pengajuan penyelesaian sengketa kepada Mahkamah Agung.

Dari paparan diatas jelaslah bahwa baik secara teoretis maupun kebijakan, adanya kerjasama pembangunan regional antar wilayah sangatlah terbuka untuk dikembangkan. Bahkan tidak berlebihan untuk mengatakan bahwa kerjasama regional sudah menjadi kebutuhan bagi setiap daerah, termasuk kabupaten/kota di wilayah Kalimantan Timur.

\section{Alternatif Model Kelembagaan Kerjasama Antar Daerah}

Secara teoretis dan pengalaman empiris, badan-badan kerjasama dapat dikategorikan kedalam beberapa model (PKP2A III LAN, 2002). Beberapa model yang umum dipergunakan adalah sebagai berikut:

\section{Kerjasama Usaha Dengan Membentuk Lembaga Baru yang Permanen.}

Dalam model ini, Badan Kerjasama dipimpin dan dikelola oleh manajemen yang terpisah dari struktur pemerintah daerah. Kedudukan pemerintah daerah hanya sebagai pemilik saham yang dalam operasionalnya akan diwakili oleh anggota komisaris badan usaha tersebut. Dengan demikian, fungsi pengendalian dan pertanggungjawaban badan usaha dilakukan melalui mekanisme rapat umum pemegang saham (RUPS). Dalam RUPS tersebut, pemda sebagai pemilik saham dapat meminta pertanggung jawaban Badan Usaha dan sekaligus pemda dapat menentukan personil untuk duduk sebagai salah satu anggota dan/atau ketua dari dewan komisaris.

\section{Kerjasama Usaha Tanpa Membentuk Badan / Lembaga Baru.}

Kerjasama ini dilakukan antar badan usaha dari suatu daerah dengan daerah lainnya, pada sejumlah tahapan aktivitas usahanya. Misalnya dalam penyediaan bahan baku, produksi, maupun dalam pemasaran barang dan jasanya. Salah satu contohnya misalnya kerjasma antara beberapa PDAM, dimana PDAM satu daerah memandang lebih ekonomis kalau 
membeli bahan baku (air) dari PDAM daerah lain, dibandingkan dengan membangun instalasi bahan bakunya sendiri. Atau satu Perusda yang memiliki pasar, dapat melakukan kerjasama dengan Perusda lain dalam pemasaran hasil usaha badan usaha daerah lainnya.

\section{Kerjasama Pelayanan Dengan Membentuk Lembaga Baru yang Permanen.}

Dalam kerjasama dengan pola ini, kelembagaan baru yang dibentuk merupakan milik bersama bagi pihak-pihak yang melakukan kerjasama. Kelembagaan ini diberi tugas untuk menangani urusan-urusan atau fungsi-fungsi tertentu, yang apabila dilakukan masingmasing daerah akan terjadi pemborosan, kemungkinan inkonsistensi kebijakan, ketidakoptimalan pendayagunaan potensi kawasan itu, atau ketidakoptimalan pelayanan yang diberikan kepada masyarakat di kawasan itu. Contoh riil mengenai hal ini adalah kelembagaan almagamasi dalam pengelolaan kebersihan / persampahan.

\section{Kerjasama Pelayanan Tanpa Membentuk Lembaga Baru.}

Kerjasama ini dilakukan antar instansi (Dinas / Lemtek) dari suatu daerah dengan daerah lainnya, untuk menyelenggarakan pelayanan tertentu, misalnya dalam penyediaan atau pembangunan fasilitas umum dan prasarana dasar seperti jalan, jembatan, gorong-gorong, sarana sanitasi (MCK), dan sebagainya. Instansi yang terikat dalam kerjasama tersebut cukup membuat kesepakatan tertulis (dokumen kontrak atau MoU), yang berisi tentang hak dan kewajiban masing-masing pihak, materi dan mekanisme kegiatan yang dikerjasamakan, serta pengaturan jika terjadi suatu hal yang tidak diinginkan. Contoh konkrit pola kerjasama ini adalah pembangunan jelan yang menghubungkan beberapa kampung yang berdekatan namun secara administratif berada di wilayah kabupaten yang berbeda. Contoh lain adalah pelayanan kesehatan bagi penduduk suatu daerah/kabupaten oleh Puskesmas yang berada di daerah / kabupaten lain.

\section{Kerjasama Bantuan Teknis (technical assistance).}

Model ini adalah kerjasama pembangunan antara daerah, dimana satu atau beberapa daerah bekerjasama dengan saling memberikan bantuan satu sama lain dalam hal-hal yang bersifat mikro atau yang bersifat teknis operasional penyelenggaraan pemerintah di daerahnya. Beberapa bentuk kerjasama technical assistance ini antara lain adalah:

- Pemberian bantuan teknis, menugaskan seorang pegawai atau beberapa pegawai yang memiliki kemampuan tertentu kepada daerah lain yang membutuhkan tenaga ahli tertentu untuk membantu mereka melaksanakan tugas pemerintahan tertentu misalnya bantuan tenaga ahli akuntan untuk membantu dalam menyusun neraca anggaran.

- Pemagangan, menugaskan seorang atau beberapa orang pegawai untuk melaksanakan program pemagangan di pemeritah daerah lain dalam meningkatkan kemampuannya dalam melaksanakan tugas.

- Perwakilan daerah, menugaskan pegawai yang memiliki keahlian tertentu untuk membantu pemerintah daerah lain dalam merencanakan pembangunan daerah yang substansinya bersinggungan dengan kepentingan daerahnya. Tenaga ahli tesebut diberikan mandat untuk mewakili kepentingan daerahnya dalam proses perencanaan atau penyelenggaraan pembangunan yang dilakukan daerah lain yang terkait dengan kepentingan daerahnya.

- Pertukaran pegawai, mengadakan program pertukaran pegawai yang dimaksudkan agar terjadi saling tukar menukar pengalaman dan pengetahuan antara daerah dalam melaksanakan pembangunan di daerahnya. 


\section{Benchmark: PAWONSARI}

Powonsari adalah kerjasama regional antar 3 kabupaten di 3 propinsi yang berbeda, yakni Kabupaten Pacitan di Jawa Timur, Kabupaten Wonogiri di Jawa Tengah, serta Kabupaten Gunung Kidul yang beribukota Wonosari di Propinsi DIY. Naskah kesepakatan (MoU) ketiga Bupati pertama kali pada 4 November 2002 yang mencakup empat kerjasama operasional (KSO) yakni: perhubungan; keamanan; kelautan/ perikanan/kehewanan/peternakan; dan ketenagakerjaan. Pada tahun 2005, ditambah lagi empat KSO pada bidang pendidikan, kesehatan dan pekerjaan umum, serta koordinasi pemanfaatan sumber mata air.

1. KSO Bidang Perhubungan. Beberapa masalah bidang perhubungan dapat diidentifikasi seperti seringnya kejadian kecelakaan lalu lintas yang melibatkan kendaraan dari daerah lain, kurangnya koordinasi dalam pengamanan event-event tertentu, semrawutnya alur trayek angkutan umum yang melintasi tiga daerah, serta perbedaan tarif retribusi untuk pengujian kendaraan bermotor. Setelah melalui pertemuan antar Dinas di Pawonsari disepakati beberapa hal yang dapat dikerjasamakan meliputi:

- Ketiga daerah dapat melakukan analisis kecelakaan bersama dan instansi tempat kejadian peristiwa memberikan informasi kepada daerah asal kendaraan melalui Tembusan Laporan Kejadian Kecelakaan.

- Ketiga daerah dapat menggunakan fasilitas pengawasan/pengawalan/bantuan petugas daerah lain dengan pemberitahuan terlebih dulu.

- Ketiga daerah dapat bersama-sama menentukan jumlah kebutuhan angkutan, survey jaringan trayek dan faktor muatan kendaraan.

- Tarif retribusi ditetapkan masing-masingdaerah namun diupayakan seragam.

2. KSO Bidang Kesatuan Bangsa dan Perlindungan Masyarakat. Untuk mengantisipasi potensi kerawanan di daerah perbatasan saat kampanye Pemilu, disepakati pembentukan pos penjagaan di perbatasan ketiga daerah tersebut.

3. KSO Bidang Kelautan, Perikanan, Peternakan / Kehewanan. Dasar perlunya KSO ini adalah kurang adanya sinergi dalam koordiansi dan pengelolaan sumber daya di sektor ini. Beberapa kesepakatan dalam KSO ini adalah:

- Pemanfaatan prasarana pendaratan kapal / perahu dan Tempat Pelelangan Ikan.

- Penangkapan dan pelestarian sumber daya ikan di pantai selatan.

- Pemberdayaan kelompok nelayan dan pembudidaya ikan pantai selatan.

- Pengawasan tata niaga hasil kelautan dan perikanan, hewan dan lalu lintas KESMAVET (kesehatan masyarakat veteriner).

- Pencegahan dan pemberantasan penyakit menular.

- Peningkatan sarana pengawasan mutasi ternak antar daerah.

- Intensifikasi kegiatan pelayanan inseminasi buatan pada sapi potong, sapi perah, kambing dan domba.

- Jaringan benih antar lapang (JABAL) komoditas palawija, dan sebagainya.

4. KSO Bidang Ketenagakerjaan. Ketiga daerah sama-sama memiliki problem kualitas SDM usia produktif dan minimnya informasi dunia kerja, sehingga sepakat untuk menggalang kerjasama pada aspek penyuluhan dan penempatan tenaga kerja, pemberian kerja darurat (PKD), serta peningkatan SDM.

5. KSO Bidang Pendidikan. Permasalahan yang sering muncul adalah adanya perbedaan kebijakan terkait dengan pemberian beasiswa yang memunculkan kecemburuan sosial bagi desa tetangga. Beberapa kesepakatan yang diatur mencakup hal-hal sebagai berikut: 
- Pendataan siswa dari tingkat SD hingga SMU di wilayah perbatasan dengan kriteria: berapa jumlah siswa yang mempunyai bakat dan prestasi, berapa jumlah siswa yang berasal dari keluarga miskin, dll.

- Upaya mensinergikan penempatan sekolah di wilayah perbatasan oleh kabupaten yang bersangkutan.

6. KSO Bidang Kesehatan. Permasalahan yang sering muncul adalah banyaknya warga di wilayah perbatasan yang kesulitan untuk berobat karena jauhnya tempat pengobatan, adanya penyakit menular di wilayah perbatasan, dan sebagainya, sehingga perlu diatur kesepakatan sebagai berikut:

- Keterpaduan dalam penanganan kesehatan di wilayah perbatasan yang diawali dengan pendataan penduduk dan jenis-jenis penyakit di wilayah perbatasan.

- Keterpaduan dalam penempatan Puskesmas atau tempat pengobatan di wilayah perbatasan.

- Mengusulkan kepada pemerintah Pusat untuk mendirikan RS Terpadu di wilayah perbatasan.

7. KSO Bidang Pekerjaan Umum. Permasalahan yang ada antara lain berupa kurang meratanya kualitas jalan antar desa di wilayah perbatasan, sehingga dilakukan KSO yang mencakup:

- Pendataan jenis jalan kabupaten yang menghubungkan dua wilayah atau lebih.

- Mengusulkan kepada pemerintah Pusat dan Propinsi untuk program peningkatan jalan.

8. KSO Bidang Penyediaan Air Bersih. Sumber mata air Sawahan di Kecamatan Pracimantoro (Wonogiri) yang sulit dijangkau karena ketinggiannya, justru dimanfaatkan Gunung Kidul karena pipa air lebih mudah dibangun disitu. Dengan adanya KSO ini, mata air dengan debit 700 liter / detik sebagian dialirkan ke Kab. Wonogiri sekitar 35 liter/detik untuk mencukupi kebutuhan air di daerah perbatasan. Proyek pipanisasi air ini didukung pendanaan dari pemerintah pusat sebesar Rp 5 miliar.

\section{Persepsi Responden Tentang Dimensi Kerjasama Antar Daerah}

Secara umum terungkap bahwa responden tidak memiliki keraguan mengenai pentingnya kerjasama antar daerah. Disini, mayoritas responden (92,9\%) menyatakan bahwa kerjasama dengan daerah lain dalam penyediaan dan/atau pemberian layanan publik di bidang-bidang kebersihan, lingkungan, serta prasarana umum adalah penting atau sangat penting, sedangkan 7,1\% lainnya menyatakan ragu-ragu. Distribusi jawaban responden ini mengindikasikan adanya kesadaran di kalangan aparatur Pemerintah Daerah untuk menempuh model-model kemitraan dan/atau kerjasama dengan pihak lain, khususnya dengan Pemerintah Daerah yang berdekatan.

Kesadaran dan kesiapan untuk melakukan kerjasama pembangunan dengan daerah lain dari jajaran aparat Pemerintah Daerah ini didukung pula oleh adanya kemauan politik (political will) dari pimpinan daerah (Bupati/Walikota). Hal ini nampak dari jawaban responden sebanyak 78,6\% mengatakan setuju, 7,1\% menyatakan sangat setuju, dan hanya $14,3 \%$ yang menjawab ragu-ragu. Meskipun hanya sebesar 14,3\%, namun jawaban "raguragu” ini perlu mendapat perhatian karena mencerminkan adanya keraguan dari pelaku pembangunan sektoral terhadap kehendak dan keseriusan pimpinan daerah untuk menggalang kerjasama dengan daerah lain. 
Dengan adanya kesadaran dan kesiapan aparat teknis untuk melakukan kerjasama dengan daerah lain, yang didukung pula oleh political willl pimpinan, maka pelaksanaan kerjasama sesungguhnya telah memiliki fundamen yang kokoh. Yang diperlukan selanjutnya adalah upaya konkrit untuk merumuskan konsep kerjasama serta pengaturan teknis implementasi kerjasama tersebut. Tanpa adanya tindak lanjut yang riil untuk menjalin kerjasama, maka kesadaran, kesiapan, kebutuhan serta kemauan politik tidak akan berarti banyak bagi proses kemajuan pembangunan dan pemberian pelayanan publik di daerah.

Sementara itu, kondisi dan tingkat kinerja pelayanan publik dipersepsikan oleh responden sebagai cukup baik dan memuaskan. Dari seluruh responden yang ada, sebanyak 14,3\% menjawab sangat setuju, dan 42,9\% menjawab setuju. Sisanya, 21,4 menjawab raguragu, $14,3 \%$ menjawab tidak setuju, dan 7,1 menjawab sangat tidak setuju. Hal ini mengisyaratkan bahwa dalam beberapa hal, kinerja pelayanan publik di daerah masih perlu mendapat perhatian serius dan upaya nyata untuk meingkatkan kepuasan masyarakat dalam bidang pelayanan tertentu. Disamping itu, perlu dipahami pula bahwa jawaban positif responden tentang kondisi pelayanan di bidang tertentu, tidak secara otomatis berarti kinerja kualitas pelayanan pada bidang tersebut sudah baik atau positif. Sebab, persepsi yang diperoleh pada penelitian ini hanya berasal dari kalangan birokrat atau pejabat pemerintahan. Selain itu, tingkat kinerja pelayanan pada sektor tertentu sangat dipengaruhi oleh berbagai variable yang cukup kompleks.

Baik buruknya kinerja pelayanan, dan tinggi rendahnya kepuasan masyarakat terhadap pelayanan bidang tertentu, secara langsung atau tidak langsung akan mempengaruhi kebutuhan daerah terhadap pola kerjasama dalam penyelenggaraan jenis layanan tertentu. Dalam kasus diatas bisa dikatakan bahwa kerjasama dengan instansi / daerah lain lebih dibutuhkan pada pengelolaan dan pelayanan sektor lingkungan dari pada pelayanan di sektorsektor lainnya. Namun pernyataan ini bukan berarti bahwa sektor-sektor kebersihan dan infrastruktur tidak membutuhkan adanya kerjasama tersebut. Jika asumsi bahwa kerjasama antar daerah dapat menjadi alternatif untuk meningkatkan mutu pelayanan, maka semakin rendah kinerja pelayanan suatu bidang, semakin perlu pelayanan tersebut dilakukan dengan pola kerjasama. Namun kerjasama tidak hanya relevan untuk bidang-bidang dengan kinerja rendah, melainkan juga sangat baik untuk bidang-bidang yang telah menunjukkan kinerja cukup tinggi agar lebih mampu mendongkrak efektivitas dan efisiensi pada bidang yang bersangkutan.

Tinggi rendahnya kinerja pembangunan bidang tertentu, antara lain ditentukan oleh adanya kejelasan tentang batas-batas kewenangan antar jenjang pemerintahan. Mengenai hal ini, persepsi responden relatif terpencar, dimana sebanyak 35,7\% menjawab ragu-ragu, dan hanya 7,1\% menjawab sangat setuju (baca: sangat jelas). Selebihnya, 35,7\% menjawab setuju. Hal ini mengilustrasikan bahwa meskipun sebagian responden telah memahami memahami secara jelas rincian dan batas-batas kewenangan kabupaten/kota serta kewenangan propinsi, namun sebagian yang lain belum memiliki pemahaman yang memadai. Jika ketidakjelasan dan kekurangpahaman terhadap pembagian kewenangan ini terus berlangsung, maka dikhawatirkan dapat menghambat pelaksanaan tupoksi instansi/organisasi yang bersangkutan. 
Mengenai kemampuan pemerintah dalam menyediakan fasilitas umum atau memberikan pelayanan, jawaban responden mencerminkan bahwa pemerintah daerah belum memiliki kapasitas SDM dan kapasitas anggaran yang memadai untuk dapat menyelenggarakan pelayanan secara optimal. Hal ini nampak dari distribusi jawaban, dimana hanya $42,9 \%$ responden yang menyatakan setuju, sementara $35,7 \%$ mengatakan ragu-ragu, $7,1 \%$ mengatakan tidak setuju, serta $14,3 \%$ menjawab sangat tidak setuju. Dengan keterbatasan kemampuan pemerintah ini, maka penyelenggaraan fungsi pelayanan semakin mensyaratkan adanya kerjasama, kemitraan, outsourcing, atau pola-pola kolaboratif lainnya. Asumsi dasar yang dipakai disini adalah bahwa pola-pola kolaboratif tadi akan mampu menutupi kekurangan yang ada pada salah satu pihak yang terikat dalam wadah kerjasama tersebut.

Terkait dengan keterbatasan kemampuan pemerintah tadi, maka sebagian besar responden mendukung pernyataan bahwa peranan pemerintah sebaiknya lebih diarahkan pada fungsi-fungsi regulasi, perencanaan, pengawasan, dan penetapan pedoman/ standar dalam bidang-bidang pelayanan tertentu atau sektor pembangunan tertentu. Konkritnya, 14,3\% menjawab sangat setuju, dan 57,1\% menyatakan setuju. Sisanya, 14,3\% menjawab ragu-ragu, dan 14,3\% lainnya tidak setuju. Paradigma seperti ini sudah sejalan dengan prinsip reinventing government yang menandaskan bahwa ciri pemerintahan katalis (catalytic government) lebih bersifat menyetir (steering) dari pada mengayuh (rowing). Salah satu implikasi terpenting dari pemerintahan katalis ini adalah pemerintah yang memberdayakan segenap potensi di daerah (baik sektor publik maupun swasta) untuk ikut serta dalam penyelenggaraan fungsi pelayanan, sementara pemerintah daerah lebih memposisikan diri sebagai pengambil atau pengatur kebijakan (regulator) dan penyeimbang (mediator).

Tuntutan untuk meningkatkan kerjasama dan/atau memberdayakan potensi daerah yang ada tadi juga didorong oleh fakta bahwa lembaga / instansi pemerintah daerah yang ada saat ini masih belum optimal (efektif dan efisien) dalam memberikan pelayanan kepada masyarakat. Gejala masih rendahnya efektivitas dan efisiensi lembaga / instansi pemerintah daerah ini tercermin dari jawaban responden sebanyak 35,7\% yang menyatakan ragu-ragu, dan 28,6\% tidak setuju. Dalam hal ini, hanya 7,1\% yang menjawab sangat setuju, dan 28,6\% lainnya menyatakan setuju. Kondisi ini tentu saja menjadi alasan lain untuk mempromosikan model-model kerjasama dalam penyelenggaraan pelayanan dan/atau urusan-urusan publik.

Disamping alasan belum efektifnya fungsi kelembagaan publik, keterbatasan anggaran juga dapat menjadi alasan utama perlunya dilakukan kerjasama antar daerah. Faktanya, instansi pemerintah selalu dihadapkan pada masalah klasik berupa kurang memadainya anggaran belanja publik. Hal inipun diakui oleh responden. Meskipun masih ada $14,3 \%$ responden yang menjawab setuju, namun 42,9\% lainnya menjawab ragu-ragu, 28,6\% lagi menjawab tidak setuju, dan 14,3\% menjawab sangat tidak setuju. Distribusi jawaban tadi menyiratkan bahwa pemerintah daerah belum mampu membiayai secara penuh seluruh aktivitas pelayanan kepada masyarakat, dan oleh karenanya perlu mencari cara dan metode pembiayaan alternatif yang inovatif.

Jika aspek kelembagaan dan keuangan / anggaran masih dinilai lemah, maka aspek kapasitas atau kemampuan SDM dinilai responden lebih baik dibanding kondisi keuangan. 
Hal ini terlihat dari 21,4\% responden menjawab setuju, 42,9\% menyatakan ragu-ragu, dan 35,7\% yang memberikan jawaban tidak setuju. Meskipun sedikit dipandang mampu, namun upaya capacity building tetap harus dilanjutkan agar dapat meningkatkan profesionalisme SDM aparatur di daerah.

Dimensi terakhir dari variable kerjasama yang diteliti adalah mengenai potensi/ kemampuan swasta untuk menyelenggarakan pelayanan umum. Dalam hal ini, responden memandang positif keberadaan, peran, dan potensi swasta dalam mengemban fungsi-fungsi sektor publik, dimana 14,3\% menyatakan sangat setuju, dan 42,9\% menyatakan setuju. Selebihnya, 21,4\% responden menjawab ragu-ragu atau kurang percaya dengan kemampuan sektor swasta, dan 21,4\% lainnya bahkan menyatakan tidak setuju. Keberadaan sektor swasta yang dinilai telah cukup kapabel ini perlu diberdayakan sebagai bagian yang tidak terpisahkan dari upaya mempercepat proses pembangunan serta memperbaiki kualitas pelayanan publik. Pada saat yang bersamaan, pelaku bisnis pada sektor privat juga harus berupaya atas inisiatif sendiri membangun kemampuan teknis dan manajerialnya sehingga dapat menjadi mitra andalan bagi instansi sektor publik.

Khusus mengenai pelayanan persampahan dan kebersihan, seluruh responden menyatakan setuju adanya sistem kompensasi. Artinya, suatu daerah yang memanfaatkan fasilitas pembuangan sampah (TPA) pada lokasi di daerah lain, maka daerah tersebut wajib memberikan kompensasi finansial maupun non-finansial kepada daerah dimana lokasi TPA tersebut berada. Dalam konteks hubungan Kota Bontang - Kabupaten Kutai Timur, maka Kota Bontang wajib memberikan kompensasi kepada Pemkab dan/atau masyarakat Kutai Timur, karena sebagian sampah di Bontang dibuang ke wilayah Kutai Timur.

Secara lebih terinci, distribusi jawaban responden terhadap dimensi-dimensi kerjasama antar daerah dapat dilihat pada table dibawah ini.

Tabel 1

Persepsi Responden tentang Dimensi-Dimensi Kerjasama Antar Daerah (n = 14)

\begin{tabular}{|c|c|c|c|c|c|c|}
\hline \multirow{2}{*}{ NO } & \multirow{2}{*}{ Item Pernyataan } & \multicolumn{5}{|c|}{ Distribusi Jawaban (\%) } \\
\hline & & SS & $\mathrm{S}$ & $\mathbf{R}$ & TS & STS \\
\hline 1 & $\begin{array}{l}\text { Kerjasama dengan daerah (kabupaten/kota) lain } \\
\text { dalam pelayanan publik adalah penting. }\end{array}$ & 42,9 & 50 & 7,1 & - & - \\
\hline 2 & $\begin{array}{l}\text { Political will pimpinan daerah (Bupati/Walikota) } \\
\text { untuk menggalang kerjasama dengan daerah lain } \\
\text { sudah cukup tinggi. }\end{array}$ & 7,1 & 78,6 & 14,3 & - & - \\
\hline 3 & $\begin{array}{l}\text { Penyediaan sarana pelayanan publik di daerah } \\
\text { sudah cukup berkualitas dan memuaskan } \\
\text { masyarakat. }\end{array}$ & 14,3 & 42,9 & 21,4 & 14,3 & 7,1 \\
\hline 4 & $\begin{array}{l}\text { Pembagian urusan / kewenangan antara Propinsi } \\
\text { dan Kabupaten/Kota dalam bidang-bidang } \\
\text { pelayanan publik sudah cukup jelas. }\end{array}$ & 7,1 & 35,7 & 35,7 & - & - \\
\hline 5 & Saat ini, kemampuan pemerintah daerah untuk & - & 42,9 & 35,7 & 7,1 & 14,3 \\
\hline
\end{tabular}




\begin{tabular}{|l|l|l|l|l|l|l|}
\hline & $\begin{array}{l}\text { menyediakan/memberikan pelayanan masih cukup } \\
\text { tinggi, baik dari segi pendanaan maupun SDM } \\
\text { pelaksananya. }\end{array}$ & & & & & \\
\hline 6 & $\begin{array}{l}\text { Peran pemerintah daerah dalam pembangunan dan } \\
\text { pelayanan publik sebaiknya difokuskan pada } \\
\text { fungsi regulasi, perencanaan, pengawasan, dan } \\
\text { penetapan standar. }\end{array}$ & 57,1 & 14,3 & 14,3 & - \\
\hline 7 & $\begin{array}{l}\text { Lembaga pemerintah (Dinas/Badan/Kantor/ } \\
\text { UPTD) yang menangani urusan pembangunan dan } \\
\text { pelayanan di daerah saat ini sudah cukup efektif } \\
\text { dan efisien. }\end{array}$ & 28,6 & 35,7 & 28,6 & - \\
\hline 8 & $\begin{array}{l}\text { Alokasi dana untuk pembangunan dan pemberian } \\
\text { pelayanan publik di daerah sudah cukup memadai. }\end{array}$ & - & 14,3 & 42,9 & 28,6 & 14,3 \\
\hline 9 & $\begin{array}{l}\text { Kualitas dan kuantitas SDM daerah di bidang } \\
\text { pembangunan dan pelayanan publik di daerah } \\
\text { sudah cukup memadai. }\end{array}$ & - & 21,4 & 42,9 & 35,7 & - \\
\hline 10 & $\begin{array}{l}\text { Potensi swasta lokal dalam bidang pembangunan } \\
\text { dan pelayanan publik cukup besar dan perlu } \\
\text { diberdayakan }\end{array}$ & 42,9 & 21,4 & 21,4 & - \\
\hline
\end{tabular}

Sumber: Kuesioner Penelitian (2005, diolah)

\section{Praktek dan Prospek Kerjasama Antar Daerah di Kalimantan Timur}

Secara umum dapat disimak bahwa penyelenggaraan suatu urusan pembangunan dan/atau pelayanan publik di berbagai kabupaten/kota di Kalimantan Timur belum didasarkan pada pola-pola kerjasama. Dan oleh karena belum ada sama sekali pola kerjasama yang dijalankan, maka di seluruh daerah yang diteliti belum dijumpai adanya naskah/ dokumen kerjasama, serta pengaturan yang lebih detail tentang substansi dan mekanisme kerjasama.

Walaupun belum ada praktek kerjasama antar daerah dalam penyelenggaraan urusan pembangunan dan/atau pelayanan tertentu, namun jajaran aparat pemerintah daerah telah memahami tentang manfaat yang dapat diperoleh dengan pola-pola kerjasama. Dalam hal ini, tujuan/kondisi yang diharapkan dari adanya kerjasama antar daerah sesuai dengan bobot kepentingannya adalah sebagai berikut:

a. Untuk meningkatkan pelayanan masyarakat.

b. Untuk mengatasi keterbatasan anggaran dan SDM daerah.

c. Untuk menghindari konflik kepentingan antar daerah.

d. Untuk meningkatkan efektivitas penyelenggaraan fungsi pemerintah.

e. Untuk meningkatkan pemasukan bagi kas daerah (PAD).

f. Meningkatkan pemerataan hasil pembangunan.

Guna mencapai tujuan / kondisi ideal diatas, maka penyelenggaraan urusan pembangunan dan/atau pemberian pelayanan umum perlu dilakukan secara kolaboratif lintas 
instansional. Dalam hubungan ini, beberapa instansi di tingkat daerah yang diharapkan dapat menjalin ikatan kerjasama menurut persepsi responden adalah sebagai berikut:

a. Untuk pelayanan kebersihan / persampahan, instansi yang perlu menggalang kerjasama meliputi Dinas PU, Dinas Lingkungan Hidup / Bapedalda, Dinas Pasar, Dinas Kesehatan, Dinas Perhubungan, dan DPRD.

b. Untuk pembangunan dan penyediaan fasilitas umum atau prasarana dasar, instansi yang perlu menggalang kerjasama meliputi Dinas PU, Dinas Tata Kota, Dinas Pertanahan, Bagian Penyusunan Program Setda, Dinas Pertanian, dan DPRD.

c. Untuk pengelolaan lingkungan hidup, instansi yang perlu menggalang kerjasama meliputi Dinas Lingkungan Hidup / Bapedalda, Dinas Pertambangan, Bappeda, Dinas Kesehatan, Dinas Kehutanan, Dinas Pertanian, dan DPRD.

Dari gambaran diatas nampaklah bahwa penyelenggaraan urusan pembangunan dan/atau pemberian pelayanan umum bidang tertentu tidak akan efektif jika tidak dilakukan secara bersama-sama secara sinergis dengan instansi lainnya. Sekali lagi, hal ini mengisyaratkan perlunya dilakukan kerjasama antar instansi (pola amalgamasi internal). Pada saat yang bersamaan, kerjasama antar daerah (pola amalgamasi eksternal) juga sangat perlu dikembangkan. Disini seluruh responden sepakat bahwa prioritas ditempuhnya kerjasama lintas daerah ini adalah dengan daerah yang bertetangga atau berbatasan.

Mengenai kelembagaan yang dipandang efektif untuk menjalankan pola kerjasama tadi, mayoritas responden mendukung ide agar kerjasama tersebut dikendalikan oleh pemerintah propinsi, dan dijalankan oleh pemerintah kabupaten / kota berdasarkan pedoman dan delegasi dari propinsi. Sebagian lain menginginkan adanya pelibatan pihak swasta (termasuk masyarakat), baik dalam hal permodalan, manajemen maupun tenaga pelaksananya. Hal ini dimaksudkan untuk mengisi kelemahan atau keterbatasan yang ada pada sektor publik (pemerintah daerah). Selain kedua pola tersebut, beberapa responden juga ada yang berpendapat agar kerjasama antar daerah dijalankan sepenuhnya oleh unsur pemerintah daerah (kabupaten/kota) yang bersangkutan.

Bahkan dibidang pengelolaan lingkungan hidup, sebagian kecil responden mengusulkan perlunya dipertimbangkan untuk membentuk lembaga pengelola khusus atau badan otorita. Secara teoretis, pola kelembagaan berbentuk otorita ini memang memungkinkan dan dapat diterapkan di daerah yang memiliki kawasan-kawasan khusus seperti pelabuhan, bandar udara, industri (industrial estate), perkebunan, pertambangan, kehutanan, pariwisata, jalan bebas hambatan dan sebagainya. Pola ini memiliki beberapa kelebihan atau keuntungan, yakni:

a. Penyelenggaraan suatu urusan atau suatu kawasan menjadi lebih terfokus.

b. Pelayanan bidang tertentu dapat meningkat.

c. Lebih bersifat independen sehingga mengurangi kadar intervensi birokrasi.

Meskipun demikian, pola otorita (khususnya di tingkat kabupaten/kota) masih merupakan kasus yang langka serta memiliki beberapa kelemahan dalam hal-hal sebagai berikut:

a. Ada potensi menimbulkan disparitas sektoral atau regional (antar wilayah).

b. Membutuhkan alokasi sumber-sumber daya khususnya dana secara spesifik dalam jumlah yang sangat besar.

c. Dalam beberapa hal sering menjadikan fungsi kontrol / pengawasan melemah, serta 
menimbulkan mis-koordinasi dan disharmoni dalam hubungan antar lembaga.

Sehubungan dengan adanya usulan untuk membentuk badan otorita tadi, maka beberapa responden setuju untuk membentuk kelembagaan yang sama sekali baru (terlepas dari kelembagaan yang telah ada), namun tetap dengan koordinasi lembaga yang telah ada sebelumnya. Namun untuk responden lain yang kurang menyetujui ide membentuk badan otorita, mereka lebih memilih untuk mengoptimalkan kelembagaan yang telah ada di masingmasing daerah, dengan menyempurnakan aspek mekanisme kerja lembaga antar daerah.

Selanjutnya mengenai pola pembiayaan kerjasama antar daerah, mayoritas responden menyepakati agar sumber pendanaan kerjasama dibebankan pada APBD Propinsi sebagai dana pokok, dan ditopang dengan APBD Kabupaten/Kota sebagai dana pendamping. Pandangan ini sejalan dengan paradigma UU Pemerintahan Daerah (UU No. 22/1999 jo. UU No. 32/2004 bahwa urusan yang bersifat lintas daerah, maka menjadi kewenangan Propinsi. Namun beberapa responden yang nampaknya tidak ingin menciptakan ketergantungan daerah terhadap Propinsi lebih cenderung untuk membebankan sepenuhnya ongkos yang dibutuhkan untuk membiayai kerjasama regional pada APBD Kabupaten / Kota yang terlibat dalam kerjasama itu secara seimbang / proporsional, serta ditunjang oleh dana swadaya masyarakat (termasuk investor lokal) secara tidak mengikat.

Aspek terakhir yang perlu diperhatikan adalah kemungkinan timbulnya sengketa antar daerah sebagai akibat pelaksanaan suatu kerjasama. Dalam hal ini, pola penyelesaian yang diajukan oleh responden pada umumnya berupa mekanisme konsensus atau secara musyawarah antar daerah yang terlibat dalam kerjasama. Namun jika mekanisme ini macet atau tidak dapat berfungsi dengan baik, maka sengketa yang ada perlu diselesaikan oleh pemerintah propinsi atau pemerintah pusat atas dasar keterangan berbagai pihak yang terkait. Atau jika dipandang perlu dapat pula menggunakan jalur mediasi dan negosiasi oleh lembaga arbitrase. Hal ini sangat memungkinkan untuk dilakukan, mengingat kerjasama pembangunan antar daerah tidak sepenuhnya tunduk pada hukum publik, namun juga dapat mengacu kepada kaidah-kaidah hukum privat/perdata.

Mencermati berbagai kondisi pragmatis pelaksanaan urusan pembangunan dan/atau pelayanan bidang tertentu tersebut, maka dapat diprediksikan adanya prospek yang cukup baik untuk memperkuat jaringan kerja antar daerah yang bertetangga. Dalam hubungan ini, beberapa prospek kerjasama yang dapat dikembangkan di wilayah Bosanggarong (Bontang, Sangatta, Tenggarong) mencakup hal-hal sebagai berikut:

a. Untuk bidang pelayanan kebersihan/persampahan, antara lain meliputi:

- Kebijakan meningkatkan kebersihan kota dalam rangka meraih Piala Adipura sebagai indikator keberhasilan manajemen perkotaan, khususnya di bidang kebersihan/persampahan. Hal ini antara lain dapat dilakukan dengan membangun TPS/TPA baru, membentuk "armada kuning" bersama, serta penggunaan secara bersama-sama terhadap asset yang dimiliki (alat-alat angkut / kendaraan, incinerator, dan sebagainya).

- Secara lebih spesifik, kerjasama pengelolaan kebersihan dapat pula dilakukan pada fungsi-fungsi khusus seperti pengangkutan dan pembuangan sampah, daur ulang sampah, pengelolaan TPA (Tempat Pembuangan Akhir), atau pengembangan teknologi penanganan sampah ramah lingkungan.

b. Untuk bidang pembangunan dan penyediaan fasilitas umum atau prasarana dasar, antara 
lain meliputi:

- Pembangunan sarana penyediaan air bersih; pembangunan perumahan/ permukiman; penanganan banjir dan aliran sungai; penyediaan infrastruktur daerah perbatasan antar daerah meliputi jalan dan jembatan, jaringan listrik/ telepon; perencanaan transportasi terpadu lintas daerah; penyusunan dan penerapan RTRW kabupaten, dan sebagainya.

- Khususnya dalam penanganan banjir musiman di Kota Bontang yang diindikasikan berasal dari luapan sungai di wilayah Kutai Timur, hal ini antara lain dapat diatasi dengan pembangunan waduk atau bendungan di wilayah Kutai Timur, sehingga dapat menampung luapan air akibat hujan besar. Keberadaan waduk/bendungan ini sekaligus dapat membawa multiplier effect dibidang pariwisata, pertanian, dan sebagainya.

c. Untuk bidang pengelolaan lingkungan hidup, antara lain meliputi:

- Pelestarian hutan lindung atau Tahura, yang antara lain dapat dilakukan dengan pendataan masyarakat perambah hutan, penataan pemukiman liar di kawasan hutan lindung atau Tahura, pemantauan bersama, pertukaran informasi yang berhubungan dengan kondisi dan kebijakan pelestarian lingkungan hidup, dan sebagainya. Hal ini terutama dapat diterapkan pada kasus pengelolaan Taman Nasional Kutai (TNK) di wilayah Kabupaten Kutai Timur dan Kabupaten Kutai Kartanegara; atau pengelolaan/pemeliharaan Kawasan Kars di wilayah Kabupaten Kutai Timur dan Kabupaten Berau.

- Secara lebih spesifik, kerjasama pengelolaan lingkungan hidup dapat pula dilakukan pada fungsi-fungsi khusus seperti pengelolaan limbah terpadu yang ramah lingkungan, pengawasan pengendalian pencemaran, kajian-kajian teknis pengendalian pencemaran, penanganan dan pemantauan Daerah Aliran Sungai (DAS), pemeliharaan Sungai Mahakam dan wilayah pesisir/pantai, dan sebagainya.

\section{Kesimpulan dan Rekomendasi}

Sebagaimana termaktub dalam UU No. 32/2004, hakikat kerjasama pembangunan antar daerah adalah upaya membangun dan meningkatkan pelayanan prima kepada masyarakat. Dan dalam realita lapangan, daerah-daerah yang telah memiliki model-model kerjasama dengan daerah lainnya ini terbukti mampu memperbaiki kinerja pelayanan di bidang-bidang atau sektor pembangunan tertentu. Ini berarti pula bahwa penyelenggaraan urusan pembangunan dan/atau pemberian pelayanan bidang tertentu dengan menggunakan pola kerjasama, berkorelasi positif terhadap upaya meningkatkan kepuasan dan kesejahteraan masyarakat.

Disamping tujuan untuk meningkatkan pelayanan kepada masyarakat, model-model kerjasama antar daerah juga dapat menjadi metode yang efektif untuk mengatasi keterbatasan sektor publik, terutama dalam aspek SDM dan Anggaran. Pada saat yang bersamaan, polapola kerjasama/kemitraan ini juga berdampak positif terhadap upaya pemberdayaan potensi sektor privat dan sektor masyarakat, sebagai pencerminan prinsip good governance. Dengan demikian nampaklah bahwa konsep kerjasama regional antar daerah memiliki spread effect yang multi facet. Untuk itu, implementasi kerjasama diyakini akan sangat bermanfaat dan dapat membantu meringankan tugas-tugas pemerintah daerah.

Kondisi obyektif pemerintahan daerah di Kalimantan Timur dan jajaran pejabatnya menunjukkan bahwa model-model kerjasama antar daerah sudah dapat djalankan / dilaksanakan dengan optimal, karena didukung oleh kesadaran akan pentingnya kerjasama, 
dukungan pimpinan daerah, yang ditopang pula oleh kapasitas sektor privat dan masyarakat. Selain itu, kondisi obyektif pembangunan juga sudah makin menuntut diterapkannya model kerjasama tersebut. Kondisi obyektif disini antara lain diindikasikan oleh banyaknya prasarana / infrastruktur dasar yang rusak di wilayah perbatasan antar kabupaten/kota, munculnya dampak-dampak lingkungan seperti banjir atau longsor akibat keterkaitan ekologis, dan sebagainya. Kondisi ini tentu harus disikapi dengan membangun komitmen bersama diantara pemerintah daerah yang berkepentingan.

Dalam prakteknya, banyak daerah belum terbiasa menerapkan pola kerjasama / kemitraan dalam penyelenggaraan urusan pembangunan dan/atau pemberian pelayanan bidang tertentu. Meskipun demikian, konsep pengembangan kerjasama sudah mulai dirancang sebagai embrio kebijakan daerah yang cukup potensial. Dengan kata lain, prospek kerjasama regional (antar kabupaten/kota) di wilayah Kalimantan Timur cukup terbuka lebar. Hal ini tinggal menunggu aksi nyata jajaran aparat pemerintah daerah untuk merealisasikan kebijakan ini (kerjasama antar daerah).

Prospek penyelenggaraan kerjasama lintas daerah di wilayah Kalimanntan Timur pada berbagai sektor terbuka sangat luas, bukan hanya pada 3 (tiga) bidang yang diteliti, namun juga bidang-bidang atau sektor pembangunan dan pelayanan lainnya. Disamping didukung oleh kesiapan SDM dan beragamnya kegiatan sektoral yang dapat dikerjakan, juga telah ada contoh sukses (success story) dari wilayah lain yang menerapkan pola kerjasamma antar daerah. Dengan kata lain, upaya benchmarking atau studi banding akan menjadi kondisi yang memudahkan pelaksanaan kerjasama antar daerah di wilayah Kalimantan Timur.

Atas dasar hal-hal tersebut diatas, maka beberapa rekomendasi berikut diyakini dapat memberikan efek pengungkit yang cukup efektif dalam membangun kerjasama antar daerah, jika benar-benar dilaksanakan dengan konsisten.

1. Dilihat dari berbagai dimensi kerjasama antar daerah, baik yang menyangkut kesiapan aparat, kesadaran akan manfaat kerjasama, dukungan pimpinan daerah, maupun potensi pihak ketiga, semuanya telah mendukung segera dilaksanakannya kerjasama antar daerah. Pada saat yang bersamaan, kemampuan obyektif pemerintah daerah relatif masih sangat terbatas sehingga menjadi faktor yang makin memperkuat alasan perlunya kerjasama antar daerah. Sayangnya, kerjasama ini belum banyak dipraktekkan dan dioptimalkan. Oleh karena itu, langkah pertama yang harus dilakukan adalah mengintensifkan komunikasi antar pemerintah daerah. Dalam hal ini, pertemuan-pertemuan regional atau pembentukan forum parlemen regional, merupakan strategi alternatif yang sangat penting untuk segera digulirkan.

2. Perlu adanya kejelasan antara kewenangan kabupaten/kota dengan kewenangan provinsi. Kejelasan batas-batas kewenangan ini akan menghindarkan terjadinya overlap / tumpang tindih atau saling lempar tanggung jawab penyelenggaraan urusan bidang tertentu. Dengan kata lain, kejelasan kewenangan antar jenjang pemerintahan ini diharapkan dapat meningkatkan efektivitas dan efisiensi program-program pemerintah daerah, khususnya dalam rangka pemberian pelayanan kepada masyarakat (public service delivery).

3. Kerjasama hendaknya dilakukan untuk semua jenis layanan dan/atau sektor pembangunan yang bersifat atau memiliki implikasi (eksternalitas) lintas daerah. Kerjasama ini hendaknya diterapkan terhadap bidang layanan / sektor pembangunan baik yang telah menunjukkan kinerja positif, maupun yang masih berkinerja rendah.

4. Untuk memberi landasan yuridis maupun politis yang lebih kuat, maka suatu kerjasama 
antar daerah hendaknya dikonsultasikan dan/atau mendapat persetujuan terlebih dahulu dari badan perwakilan daerah (DPRD). Hal ini didasari oleh pengalaman beberapa daerah lain di Indonesia, suatu perjanjian seringkali hanya berakhir diatas kertas dan tidak dapat terealisasikan pada tahap operasional. Dengan kata lain, fungsi DPRD lebih sebagai moral force untuk mengontrol dan menjamin bahwa suatu perjanjian yang telah disepakati dengan daerah lain harus dapat berjalan sebagaimana mestinya. Jika hal ini dilakukan, maka sekaligus dapat menjadi bukti kuatnya komitmen dan political will jajaran pimpinan daerah untuk mensukseskan program pembangunan daerah melalui pola kemitraan / kerjasama.

5. Instansi / Dinas teknis perlu segera mengidentifikasi kebutuhan kerjasama pada lingkup tugas dan tanggung jawabnya masing-masing. Upaya identifikasi kerjasama ini antara lain meliputi daerah yang perlu diajak kerjasama, tujuan dan sasaran kerjasama, cakupan/bidang-bidang yang dikerjasamakan, mekanisme pembiayaan dan penetapan tim pengelola kerjasama, hak dan kewajiban pihak-pihak terkait, sanksi jika terjadi pelanggaran terhadap kesepakatan yang dicapai, masa berlaku kerjasama dan kemungkinan tindak lanjutnya, pola pembagian keuntungan (jika ada), serta aspek-aspek teknis lainnya.

6. Keterbatasan anggaran dan SDM pemerintah dalam pelayanan umum adalah hal yang lumrah, dan oleh karenanya harus dicarikan pemecahannya. Dalam hal ini, pola-pola kerjasama, kemitraan, outsourcing, kontrak kerja, merupakan opsi kebijakan yang layak dikembangkan, sementara privatisasi merupakan opsi kebijakan yang dapat dipertimbangkan. Untuk itu, pemerintah daerah (Provinsi maupun Kabupaten/Kota) hendaknya dapat melakukan analisis yang komprehensif tentang prospek penyelenggaraan pelayanan umum dengan pola-pola tersebut diatas.

7. Efektivitas kelembagaan / instansi pemerintahan daerah masih perlu terus ditingkatkan. Secara internal, beberapa langkah yang dapat ditempuh meliputi peningkatan kualitas manajemen perencanaan dan pengawasan, peningkatan intensitas monitoring dan evaluasi, penajaman visi dan misi serta prioritas program dan kegiatan, pengembangan kapasitas SDM, dan sebagainya. Sedangkan secara eksternal, penguatan efektivitas kelembagaan dapat dilakukan dengan memberdayakan potensi mitra kerja (khususnya sektor swasta), mengoptimalkan sumber-sumber penerimaan non-pemerintah, menstimulasi kapasitas kelompok masyarakat, dan sebagainya.

8. Secara kelembagaan, perlu diperkenalkan konsep solidaritas hulu - hilir (upstream downstream solidarity). Kabupaten Kutai Timur - Kota Bontang adalah contoh dua daerah yang memiliki pola hubungan hulu - hilir ini. Secara umum terdapat kondisi dimana daerah hilir cukup tergantung pada daerah hulu, misalnya dalam hal supply sumber air bersih. Disisi lain, daerah hilir juga sering menerima dampak dari aktivitas di hulu, baik berupa pencemaran, banjir, dan sebagainya. Mengingat adanya keterkaitan yang sangat erat antara daerah hulu dan hilir tadi, maka perlu dikembangkan adanya kebersamaan dan solidaritas baik dalam hal pembagian keuntungan (benefit sharing) maupun pembebanan kerugian / dampak yang mungkin timbul (cost sharing). Dalam hal ini, mekanisme insentif - disinsentif dapat pula diterapkan tergantung pada konteks atau kasus yang terjadi. Dan dalam rangka menjalankan kewenangan dan kepentingan masingmasing, kedua daerah (hulu dan hilir) dapat membentuk kelembagaan khusus yang terdiri dari perwakilan kedua daerah, atau membentuk kelembagaan secara terpisah (di daerah masing-masing) namun diikat oleh kerjasama / perjanjian tertentu. Dengan demikian, pola solidaritas hulu - hilir ini dibangun berdasarkan pada pendekatan kebutuhan (needs approach) dan bukan pada pendekatan hak (rights approach).

9. Untuk mempercepat penerapan model kerjasama dalam penyelenggaraan urusan pembangunan dan/atau pemberian pelayanan bidang tertentu, maka Gubernur dapat atau perlu mengambil inisiatif dengan mengeluarkan Surat Edaran atau Petunjuk Teknis 
tentang penyelenggaraan kerjasama pembangunan antar daerah di wilayah Provinsi Kalimantan Timur. Selanjutnya, Biro Pemerintahan (beserta Biro Hukum) Setdaprov dapat menindaklanjuti dengan melakukan fasilitasi dan bimbingan teknis kepada berbagai kabupaten/kota yang potensial untuk mengggalang kerjasama.

\section{Daftar Pustaka}

Desai, Vandana and Rob Imrie, 1998, “The new managerialism in local governance: Northsouth dimensions", in Third World Quarterly, Vol 19, No. 4, pp 635-650.

Frank, Flo and Anne Smith, 2000, The Partnership Handbook, Ministry of Public and Government Services, Canada.

IRDA, 2003, July, Indonesian Rapid Decentralization Appraisal (IRDA): Third Report, Jakarta: Asia Foundation. Available online at http://www.asiafoundation.org/pdf/IRDA3-english.pdf

Jones, Gavin W., 2001, Studying Extended Metropolitan Regions in South-East Asia, Paper presented at the XX1V General Conference of the IUSSP, Salvador, Brazil, 18-24 August 2001. Available at http://www.iussp.org/Brazil2001/s40/S42_02_Jones.pdf

Knip, Peter, 1996, City to City Cooperation: A Network with Promising Opportunities, in "Strategies for Development", New York: United Nations.

Lembaga Administrasi Negara, 2004, Pengelolaan Penyelenggaraan Kerjasama Antar Daerah: Tinjauan Atas Beberapa Ketentuan dan Substansi Dalam Penyelenggaraan Kerjasama Antar Daerah, Jakarta.

PKP2A I LAN, 2002, Hubungan Kerjasama Pembangunan Antar Daerah, laporan hasil penelitian, Bandung. , 2004, Kajian Tentang Pengelolaan Bersama (Joint Management) Pelayanan Persampahan Di Wilayah Perkotaan, laporan hasil penelitian, Bandung.

Utomo, Tri Widodo W., 2004, Regional Development Management In Indonesia Within The Framework of Decentralized Governance (Case Study of The Sumatran Development Forum and The Greater Bandung Regional Development), Ph.D. research proposal, Nagoya University. Tersedia online di http://www.geocities.com/mas tri/

Yusuf, Moch., 2005, Uniknya Pawonsari, Payungi Tiga Kabupaten Dari Tiga Provinsi: Kerjasama Antar Daerah Pacitan, Wonogiri dan Gunung Kidul, Textbook No. 4, Praktek Sukses Pembangunan Daerah, Jakarta: CESS \& JPIP.

World Bank, 2003, Cities in Transition: Urban Sector Review In an Era of Decentralization in Indonesia, Dissemination Paper No. 7, Urban Sector Development Unit Infrastructure Department, June 30. Available online at http://wbln0018.worldbank.org/eap/eap.nsf/Attachments/03-0919-CitiesintransitionEng/\$File/Citiesintransition-Eng.pdf 